DOI 10.37882/2500-3682.2021.07.02

\title{
ДИССКУСИИ О ФИЛОСОФИИ ИСТОРИИ НА РУБЕЖЕ ВЕКОВ
}

\section{DISCUSSION ABOUT THE PHILOSOPHY OF HISTORY AT THE BORDER OF THE AGE \\ L. Andreeva}

Summary: In modern Russian philosophy there is no single point of view on the subject of the philosophy of history, therefore the purpose of this article is to analyze the approaches to the philosophy of history that have developed at the turn of the XX-XXI centuries and to derive their own definition of the philosophy of history. According to the author, in the center of philosophical and historical knowledge is the idea of history, which is a world outlook universal that includes rational theoretical knowledge, epistemological faith and an artistic image.

Keywords: philosophy of history, historical process, historical knowledge, historical epistemology, idea of history.

\author{
Андреева Людмила Сергеевна \\ К.ф.н., дочент, Владимирский государственный \\ университет имени А.Г. и Н.Г. Столетовых \\ humbab@mail.ru
}

Аннотация: В современной отечественной философии нет единой точки зрения на предмет философии истории, поэтому целью данной статьи стал анализ подходов к философии истории, сложившихся на рубеже XX-XXI веков и выведение собственного определения философии истории. По мнению автора в центре философско-исторического познания находится идея истории, представляющая собой мировоззренческую универсалию, включающую в себя рационально-теоретическое знание, эпистемологическую веру и художественный образ.

Ключевые слова: философия истории, исторический процесс, историческое познание, историческая эпистемология, идея истории.

Третья трудность, с которой мы встречаемся при определении предмета философии, связана с тем, что вслед за предметом философии и предметом истории эволюционирует и предмет философии истории.

В современной отечественной философии не сформировалось единой точки зрения на предмет философии истории. Значительная часть авторов придерживается взгляда, получившего распространение еще в литературе советского периода, что исторический материализм и есть философия истории. Этот взгляд закрепился в философских учебниках и словарях.

Начало такому пониманию философии истории положил В.Ф. Асмус в известной работе «Маркс и буржуазный историзм», вышедшей в 1933 году. На позиции, близкой к В.Ф. Асмусу, сегодня стоит И.А. Гобозов, который следующим образом определяет предмет философии истории: «Философия истории исследует имманентную логику развития человеческого общества, единство и многообразие исторического процесса, проблемы социального детерминизма и социального прогресса. Она дает теоретическую реконструкцию исторического прошлого, устанавливает истинность исторических фактов и событий» $[4$, с. 16$]$.

Б.Г. Могильницкий так же считает, что исторический материализм «выступает в отношении исторического познания в качестве общей теории и методологии, формирующей всеобщие принципы подхода к осмыслению конкретных исторических явлений и процессов» [7, с. 23].

В современной философии истории термин «исторический материализм» заменяется понятием «социальная 
философия». Проблемное поле социальной философии в настоящее время значительно превосходит предмет исторического материализма и вообще не имеет строго очерченных границ.

В связи с наблюдаемым в настоящее время эпистемологическим поворотом в исторической науке стали заметны две тенденции в определении предмета философии истории. Первая тенденция заключается в формировании самостоятельной дисциплины - теории и методологии истории. Данная тенденция во многом была обусловлена исследованиями Ковальченко И.Д., Коршунова А.М., Иванова Г.М. и др. в области методологии истории.

Вторая тенденция порождена, как пишет М.А. Кукарцева, переходом в гуманитарной области исследований от модернизма к постмодернизму. Следствием этого явилось то, что философия истории все больше превращается в историческую эпистемологию, т.е. в знание о методологии познания истории, в знание об историческом знании [5].

Наряду с указанными выше подходами к определению философии истории заслуживает быть отмеченным интерес к онтологии истории. Так, в третьем издании учебника «Введение в философию» авторы видят задачу философии истории «определить, является ли история человечества универсальной, единой в своих основах, либо расчлененной на несовместимые части, а так же каковы объективные критерии и ступени поступательного развития общества, какие из них она уже прошла, а какие ей ещё предстоит пройти» [2, с. 504].

Таким образом, в дискуссиях о философии истории сохраняются три основных направления, сложившиеся на рубеже XIX - XX веков, но сохраняются в модернизированном виде, с привлечением новых аргументов.

Первое направление, как мы видим, исходит из того, что философия истории должна быть исторической эпистемологией. Если философия истории претендует на то, чтобы быть наукой, то Книга Истории не должна отличаться точностью знания от Книги Природы. Философско-историческое знание обязано соответствовать тем же критериям научности, что и естественнонаучное знание. Поэтому предметом философии истории может быть само историческое знание, а не действительные исторические процессы и факты. Представители первого направления акцент делают на гносеологические проблемы философии истории.

Второе направление считает, что философия истории является теорией всемирно-исторического процесса, но опирается оно на новую историю, которая получила название научной, глобальной, универсальной. Вот что пишет об этом Б.Г. Могильницкий: «Наряду с микросистемным анализом свидетельством возрождающегося интереса к макросистемным построениям являются оживленные дискуссии вокруг проблем глобальной истории... В этих дискуссиях глобальная история, или глобалистика, позиционируется как одно из самых перспективных направлений социально-исторической мысли». Авторы, работающие в рамках второго направления, предпочтения отдают онтологическим вопросам истории.

Третье направление концептуально представлено в работах В.М. Межуева, в частности в его статье «Философия истории и историческая наука». Лапидарно суть его концепции можно выразить следующим фрагментом статьи: «Люди всегда жили в истории, но только тогда, когда они начинают осознавать ее особую ценность для себя, возникает «целостная концепция философии истории», ставящая своей задачей выразить эту ценность рациональными средствами, представить её в виде более или менее систематизированной «идеи истории». Философия истории есть тем самым синоним не просто знаний о далеком или близком прошлом, но знание о содержащихся в трудах философов идеи истории» [6, с. 80]. Концепция В.М. Межуева представляется весьма продуктивной.

Обобщая приведенные определения философии истории, можно было бы предложить следующее определение философии истории: философия истории есть теория всемирно исторического процесса и одновременно выступает как историческая эпистемология. В центре философско-исторического познания находится идея истории.

Идея истории не является только философской категорией или историческим понятием. Скорее это мировоззренческая универсалия, которая включает в себя и рационально-теоретическое знание, и эпистемологическую веру, и художественный образ... Идея истории является общим названием целого комплекса философских и исторических проблем, которые присутствуют в ней в свернутом виде. Идея истории - это обобщенный образ целой системы знаний и представлений о цели, смысле, направленности, логике истории, сути историзма, самой ценности истории и ценности исторического знания. Следовательно, идея истории заключает в себе онтологическое, гносеологическое, эпистемологическое и аксеологическое содержание, поскольку отражает всю многомерность истории.

Идея истории выполняет двоякую роль в историческом познании. Во-первых, она оказывается предпосылочным знанием, предпониманием, осуществляя тем самым регулятивную функцию. Во-вторых, идея истории - это идеальный художественно-логический образ исто- 
рии, т.е. адекватно, доказательно и целостно отражающий всемирно - исторический процесс.

Историк не может обойтись без Идеи истории, без присутствующего в его сознании образа истории. Но сам выработать такую идею он не может, поскольку занят исследованием лишь фрагментов истории, т.е. исторического процесса, ограниченного временными и пространственными рамками. При всем многообразии определений предмета истории все они в конечном итоге сводятся к утверждению, что история изучает закономерности конкретных форм общественной жизни.

Ознакомившись с основными направлениями понимания философии истории проведем разграничительные линии между философией истории и историей, высветим их взаимозависимость и взаимодополняемость в познании исторической реальности.

1. Первый вывод, вытекающий из проведенного анализа, заключается в том, что историческая реальность многомерна. И взгляд на неё философа и историка - это разные измерения истории. Отсюда и различные образы истории.

2. Историческая наука, несмотря на растущие тенденции к теоретизации исторических исследований, всетаки остается преимущественно наукой эмпирической. История имеет дело с явлениями преходящими, локальными, её предмет ограничен прошлым и настоящим. Как писал Гердер: «История - это наука о том, что реально существует, а не в том, что могло бы быть согласно тайным намерениям судьбы» [3, с. 173]. С этой точки зрения, выражение «история не знает сослагательного наклонения» справедливо.

Однако философия истории по самой природе философского знания не может ограничиться только реально сущим. Её в равной мере интересует прошлое и настоящее в их отношении к будущему. Для большинства историков предмет истории - события, деяния, совершенные в прошлом. Они видят задачу в новой интерпретации прошлого, опираясь на новые факты, источники.

3. Философия истории изучает всемирную историю как Тотальность, используя для этого весь культурный арсенал, все универсалии культуры. Благодаря тому, что философия всегда отдает предпочтение единому, всеобщему, целому, философии удается осуществить синтез эмпирического знания и философско-рефлективного. Такой синтез возможен потому, что философия рассматривает действия человека «в просвете бытия». Выражаясь языком М.М. Бахтина, когда «уже - не бытие» и «еще - не бытие». Именно такое бытие является, строго говоря, историческим, поскольку быть в «просвете бытия» значит быть одновременно в прошлом, настоящем и будущем. Историческое бытие дано «не в категориях временного бытия, а в категориях ещё - не-бытия, в категориях цели и смысла, в смысловом будущем...» [1, с. 1516]. Идея истории - изображение исторического бытия человека в категориях цели и смысла.

Подобную мысль мы находим и у Ясперса, который в работе «Истоки истории и её цель» говорил: «История становится таковой лишь посредством единения всеобщего и индивидуального, но таким образом, что она показывает индивидуальность неповторимого значения, единично-всеобщее. Она есть переход как выражение бытия» [8, с. 243].

Историк так не может смотреть на историю в силу специфики самого исторического познания. И здесь мы подходим еще к одному существенному отличию взглядов философа и историка на историю.

4. Этот отличительный момент аргументировано обосновал В.М. Межуев. Он его усматривает в том, что философ «при выработке идеи истории действительно имеет дело с сознанием. Но не одних лишь историков, а всех живущих с ним людей... всех, кто принадлежит к одной с ним исторической эпохе. В своем понимании идеи истории он руководствуется именно этим историческим «самосознанием эпохи», в которой сам существует и мыслит» $[6$, с. 81].

Самосознание эпохи - это отношение людей к своей истории, к своему месту в ней, свое видение будущего. Все это находит отражение в их умонастроении, психологическом состоянии, хотя при этом они могут и не ставить напрямую вопрос о смысле своего бытия в истории.

Философия истории и есть мыслящее рассмотрение исторической эпохи через проникновение в её самосознание.

Проведенное разграничение между философией истории и историей одновременно показало их взаимозависимость и взаимосвязь, необходимость друг для друга.

Философия истории не умаляет самостоятельность истории и не превращает историю в иллюстрацию философской идеи истории. Философия истории не могла возникнуть раньше, чем историческая наука достигла определенной зрелости. Историческая мысль явилась основанием для появления философии истории, из потребностей исторической науки родилась философия истории.

В эпоху, на рубеже XVIII - XIX веков, когда историческая реальность стала обретать черты всемирной исто- 
рии, у истории появилась потребность в целостном осмыслении хода истории, в идее истории. И философия ответила на эту потребность.
В заключение еще раз повторим: философия истории изучает огромный комплекс проблем, объединяемых в систему Идеей истории.

ЛИТЕРАТУРА

1. Бахтин, М.М. Эстетика словесного творчества / М.М. Бахтин. - М.: Искусство, 1986.

2. Введение в философию: учеб. пособие для вузов / [И.Т. Фролов и др.]. - Изд. 3-е, перераб. и доп. - М.: Республика, 2005.

3. Гердер, И. Идеи к философии истории человечества / И. Гердер М.: Наука, 1977.

4. Гобозов, И.А. Введение в философию истории / И.А. Гобозов. - М.: Тейс, 1999.

5. Кукарцева, М.А. Современная философия истории США / М.А. Кукарцева. - Иваново: Иван. гос. ун-т, 1998.

6. Межуев, В.М. Философия истории и история / В.М. Межуев // Вопросы философии. - 1994. - № 4. - С. 74-86.

7. Могильницкий, Б.Г. Введение в методологию истории / Б.Г. могильницкий. - М.: Высшая школа, 1989.

8. Ясперс, К. Смысл и назначение истории / К. Ясперс. - М.: Политиздат, 1991.

( ) Андреева Людмила Сергеевна (humbab@mail.ru).

Журнал «Современная наука: актуальные проблемы теории и практики»

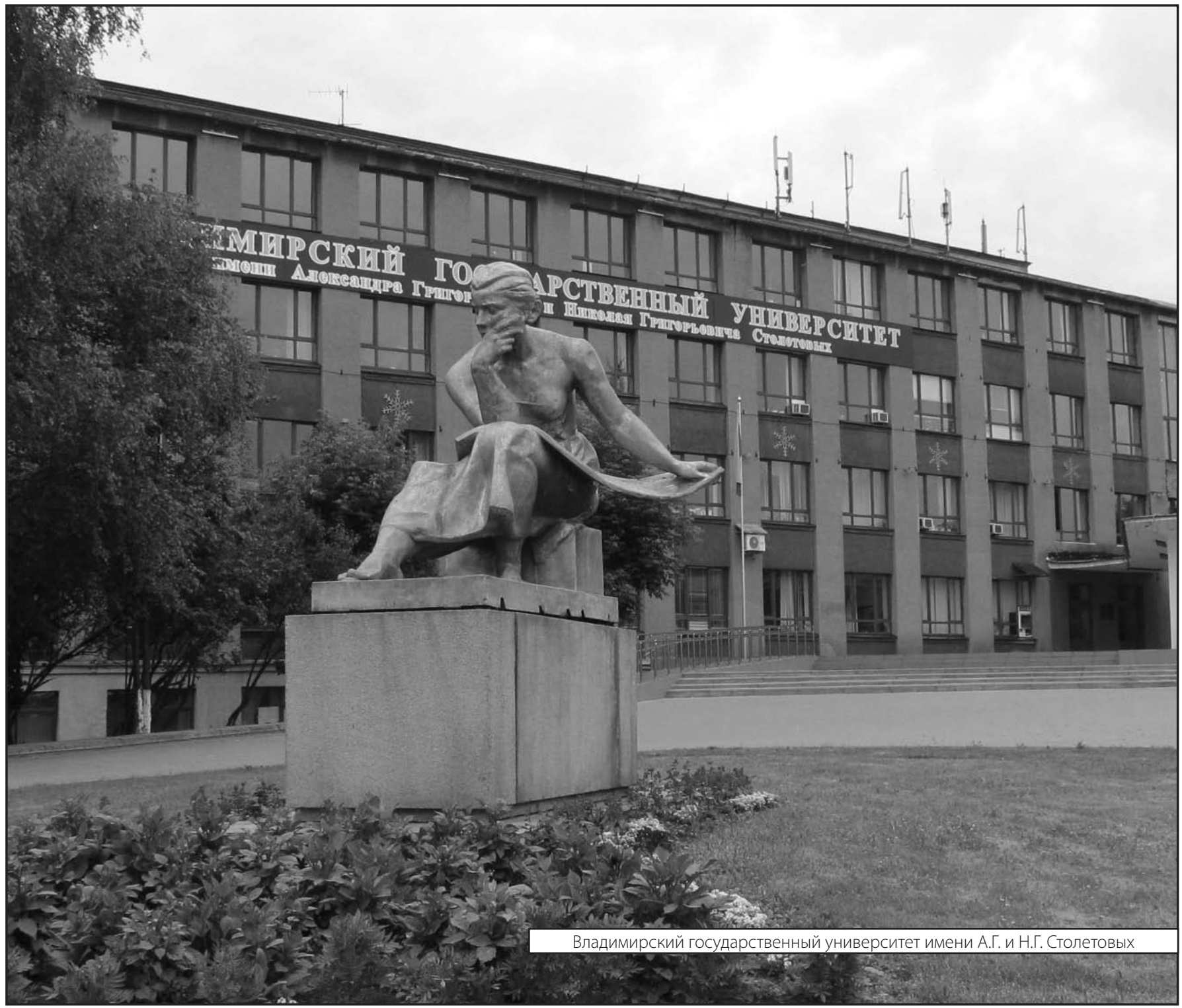

